\title{
Historical Relationship between the Buddhists and the Muslims in Sri Lanka
}

\author{
Ahamed Sarjoon Razick \\ Doctoral Candidate, The National University of Malaysia (UKM), Malaysia, Lecturer, \\ South Eastern University of Sri Lanka, University Park, Oluvil, Sri Lanka \\ sarjoonra@seu.ac.lk
}

Assoc. Prof. Dr. Ahmad Sunawari Long

Department of Theology and Philosophy, The National University of Malaysia (UKM), Malaysia

Assoc. Prof. Dr. Kamarudin Salleh

Department of Theology and Philosophy, The National University of Malaysia (UKM), Malaysia

\section{Doi:10.5901/mjss.2015.v6n4s2p278}

\section{Abstract}

That Sri Lanka is a pluralistic nation is an undeniable fact. It is the home of many communities which have contributed to its being for a long time. It is this variety, this unity in diversity, which gives it strength and beauty. In this multi-ethnic social environment, members of all communities live in peace and harmony with in social integration one with another. Accordingly, since settling down in the island more than1200 years ago, the Muslims established very cordial ties with the Buddhist people in Sri Lanka. The relationship between them may be cited as a unique example of ethnic harmony in multi-religious societies. Evidently, this is a longstanding relationship formed over a very long period of time and developed and preserved with trust and good understanding between these two communities. As such, it has stood the test of time and has been able to withstand the numerous attempts made by various colonial powers and chauvinistic racist elements to destroy it. Given the above background, therefore, the purpose of this paper is to identify historical relationship between the Buddhists and the Muslims in Sri Lanka in order to identify the changing nature of the relationship from the early Arab-Muslim settlements to the end of civil war in 2009.

Keywords: history, relationship, Buddhists, Muslims, Sri Lanka

\section{Introduction}

As a small pluralistic state, Sri Lanka has been cherished historically. This is a multi-racial social environment; members of all communities lived in peace and harmony with social integration with one another. Each community practised and its own religious cultural values. They also shared each other's prosperity and adversity. Through this way, the people of different religious groups were able to keep up the solidarity amongst them. In Sri Lanka, the Sinhalese are the main ethnic group, consisting $74.9 \%$ of the population; among them the Sinhala-Buddhists are $70.19 \%$ (Census of Population and Housing, 2012). They speak Sinhala an Indo-Aryan language. The Tamils are the second major ethnic group, consisting 15.37\% (Census of Population and Housing, 2012) of the population that includes Sri Lankan Tamils and Indian Tamils. The Muslims of Sri Lanka form the second largest minority in the island next to Tamils and consisting $9.7 \%$ of the country's population (Census of Population and Housing, 2012) and the Muslims are spread out in all twenty five administrative districts of the island.

The relationship between the Buddhists and the Muslims has been tightly linked socially and culturally from the early period of Muslim arrival in Sri Lanka. The Arab Muslim traders and local Muslims contributed immensely during the regime of Buddhist leaders to protect and to expand their reigns. During the $19^{\text {th }}$ and the $20^{\text {th }}$ centuries, many Muslim leaders and scholars toiled hard for the independence of Sri Lanka from colonial ruler (Farook, 2014). They safeguarded the territorial integrity and sovereignty of the country irrespective of ethnic, religious and lingual differences. After independence, the relationship between the Buddhists and the Muslims was so strong that they shared and cared with mutual respect and understanding. Muslims have been identified as a peace loving community maintaining societal and ethnic harmonious relations with the neighbours with whom they live too as well. Further, politically too, the Muslims have been maintaining a very good relationship with the Buddhist rulers (Haris, 2010). This cordial relationship with the 
Buddhists and their rulers made the Muslims one of the privileged communities in Sri Lanka (Razick, Long, \& Salleh, 2015). Given the above backdrop, therefore, the purpose of this paper is to identify historical relationship between the Buddhists and the Muslims in Sri Lanka in order to identify the changing nature of the relationship from the early ArabMuslim settlements to the end of civil war in 2009.

\section{An Analysis of the Historical Relationship between the Buddhists and the Muslims}

Both the ancient and modern history of Sri Lanka provides us with abundant proofs of peaceful cohabitation between the Buddhist and the Muslim communities regardless of all their religious and cultural differences. Political and trade relationships were very strong. Both communities showed their collaboration and cohabitation in a commendable manner. Thus, this topic analyses the relationship in prior to colonial, during the colonial and post-colonial periods as follows.

\subsection{Prior to colonial rule (before 1505)}

The relationship between the Buddhists and the Muslims is hundreds of years old. The Arab relationship with Sri Lanka which emerged in the ancient and maritime periods was continued after the arrival of Islam to Sri Lanka. Primarily, the Arab traders maintained a wonderful trade link with Sri Lanka and placed their ancestry in this country. In the $7^{\text {th }}$ Century, with the emergence of Islam, the Arabs converted to be Muslims; consequently the relationship between the Arab Muslims and Sri Lanka developed high up and became very strong. The dominance of Islam likewise proved a worldwide force. As a result, the relationships that originated as industrial attachments expanded to other regions such as internal and external trading, defence, foreign relationship, the settlements of the Arab-Muslims and the lasting occupants (Ameen, 2000). This association has grown over a very long period of time and, as a result, grew together with the Buddhist populace to almost $50 \%$ of the life time of Buddhism in Sri Lanka (Yehiya, 2013). This relationship with Buddhism formed and developed with great understanding and trust between these two groups.

The Muslims have a bright history of peaceful shared relations in Sri Lanka (Yusoff, Hussin, \& Sarjoon, 2014) particularly their relation with the Buddhist community. The Arab merchants espoused that the local women were generally a blended race with a substantial infusion of Buddhists and Dravidian blood in the early phase of Muslim settlements over Sri Lanka. This happened with the assent of Sri Lankan kings; they permit Muslims to settle down in the Island. This is because there were some socio-historical, political and economic purposes behind such concession offered to the Muslims in the early phase of the history of Muslims in Sri Lanka. Kamilika Peiris (2013) identifies the following socio-religious and economic reasons for the Muslim settlements and its development in Sri Lanka.

1) Sinhalese kings' economic interests: During those times Sinhalese individuals were only paid attention in cultivating and infrequently dared to venture out of the Island for dread of their existence. The Muslims overwhelmed the trade on the ocean and the lands. Thus, the Sinhalese kings supported and favoured the Muslim settlements in Sri Lanka for economic and trade interests; because Muslims had a big link with overseas trade and politics; a number of kings sent some Muslims as ambassadors to a few Muslim nations. Dewaraja (1994) points out that Al-Haj Abu Uthman was sent by the Sinhalese king Buvanekabahu I to Egypt to the Mamluk court to discuss developing the trade link in the $13^{\text {th }}$ century. Muslims constructed Ceylon as a well-known place in the Middle East by this trade expansion furthering their contacts with the Muslim world. The Sinhalese kings licensed Muslim settlements because of they brought wealth and income for the success to the Island.

2) Religious tolerance of local Sinhalese is an additional primary factor that helped in the development of Muslim settlements in Ceylon. It was unbelievable that Muslims would have settled down in Ceylon during those times without authorized invitation of Sinhalese kings and their people. The Sinhalese people were very kind and gracious by nature in urging Muslim settlements. It was the common interests of both groups allowed for the Muslim settlement in the country of Sri Lanka.

The well-known traveller Ibn Batuta (1344) records the history of Muslims in Sri Lanka in his travelogue:

"at the end of $7^{\text {th }}$ century a group of Muslim traders had settled and established well in Ceylon. Arab people were fascinated due to its delightful common quality and beautiful natural eminence".

This might have led the way for the lasting settlement. Moreover, historical backdrop attests that the progenitors were promptly welcomed by the kings in those days. A large portion of them lived in the seaside areas with peace and harmony with the local people and they maintained trade and social contacts with Baghdad Islamic Empire and other Islamic metropolis (Pieris, 2013).

Another interesting historical fact is when 'Siripada' (Adam's Peak) got connected with Adam's fall from Paradise in 
the ninth century the Muslim merchants integrated themselves to the Sinhalese people who were dependably tolerant in spiritual matters. It is notable that there was no disagreement arising from the fact that the newcomers were disputing the age old belief of the Buddhist people that the impression on the rock was the footstep of the Gautama Buddha. Marco Polo traces an observation at the time that the Buddhist people believed that the shrine on the peak, the tooth, hair and bone relics enshrined in various places in the island, all belong to Buddha; whereas the Arabs, who came on pilgrimage in large numbers, held that they all belong to Adam. However, there was no clash despite the different views (Latham, 1958).

Dewaraja (1994) argues that the Muslims got one thousand years of peaceful history in Sri Lankan soil and they managed to get on well with Buddhist people right through this long length of history. She specifies that the Muslims have a few traditional Buddhist family names which clearly imply their inherited family roots of Muslims today; at the same time, the Muslims keep up their original kin trees which preserved their religious personality to their Islamic names; Sinhala names were used in their legal documents testifying to origin and proprietorship of movable and immovable properties.

Noteworthy in this respect, in the Middles Ages the Caliphate of Islam moved up to Delhi, in Indian sub-continent during this time. Notably, that Caliphate invade and were victorious over North India was because of an incident that the Hindu pirates assaulted a vessel sailing from Sri Lanka which consisted of Sri Lankan voyagers on the Hajj pilgrimage by carrying token offerings from Buddhist rulers to the head of the state of Iraq. It was prompted to capitulate India under the direction of 'Muhammed Bin Qasim' due to this piracy on Hajj pilgrims (Yehiya, 2013). In addition, there are a few historical evidences which prove the great relationship between the Buddhists and the Muslims, likewise the attendance of the military advisors of Muslims and the mariners to advise the Buddhist Kings against the Portuguese, Dutch and British invasion, presence of the Muslim physicians and the Trade counsels, the Muslim soldiers in Buddhist defence force and their contribution in battle fields against the colonial conquests (Hussein, 2013).

During the Middle Ages, the Muslim kingdom which enlarged from the south of France in the North to the Southern parts of Africa in the south and from the North Africa in the West to India in the East, acknowledged Sri Lanka likewise as a preferred and gracious country. In this manner the Islamic Caliphate had no awful intention of capitulation of Sri Lanka. Also It was historically evident that, at whatever point, there were interior disputes within the empire around the higher positions of political administration. There were occurrences of political refugees opting for the country of Sri Lanka as their preferred place by applying for asylum. A few refugees were in permanent residence here (Ameen, 2000). By this historical record, it could be maintained that these two existed in a two-way relationship; one, the Muslim Empire recognized the country of Sri Lanka as one of the most friendly and favoured nation. On the other hand, the Buddhist kings and their people took the Muslim people as their associates and cohabitants.

\subsection{Under the Colonial Rule (1505-1915)}

The Portuguese invaded the island in search of new colonies in 1503 with an eye for spices and to broaden their Catholic religion. The Muslims were challengers in both religion and trade and, thus they were ill-treated by the Portuguese for more than one hundred and a half years. The Muslims were also annihilated in Matara by Portuguese. This aggravation, repression and persecution against the Muslim people also continued during the Dutch, but were simplified to a large extent throughout the British colony.

When the Dutch persecuted the Muslims to their seaside settlements, the Muslims went to the Kandyan territory. Senerat (1604-1635) and Rajasimha II (1635-1687) settled those Muslims in the Eastern bank. King Senerat settled a huge number of Muslims as well as Tamils in Dighavapi in Batticaloa region to resuscitate paddy cultivation (Razick, 2007). The Muslims were welcomed by the Kandyan regime and its people. They were incorporated into the Kandyan public arena mainly by assigning them the duties which identified with the King's administration. They were made a transport department so-called 'Madige Badda'. Then the Muslims were permitted to do arecanut business, which was the monopoly of royal. The Muslims in Uva region, who was close to the salterns, had to transport the salt as a duty of their mandatory service (Dewaraja, 1994). In addition to this, select the Muslims were involved in 'Maligawa' sacraments and were given 'Maligagam' lands. Their sense of duties included the salt, with the silversmith advancing the function of 'Kariya Karavanarala'. Therefore, the Muslims contributed -however minimally- to the administrative and sacrament aspects of the 'Dalada Maligawa'. Also the Muslims served similarly as weavers, barbers, lapidarists and tailors (Dewaraja, 1994).

Moreover, the Sinhalese kings and the people very much appreciated the contributions made by the Muslim traders whose nomadic trading activities brought them to remotest regions of the state. These venturesome traders who meticulously penetrated into the long distanced interiors of the territory are known to have brought with them for buying and selling and exchange goods suited for the simplest necessities of villagers including foodstuffs, clothes and 
jewellery such as a paramount protein supplement, dried fish, which were not simply procurable in those times (Hussein, 2013). In addition, Dewaraja (1994) points out that,

"Right through from the Anuradhapura period to Kandyan times there was a Muslim lobby operating in the Sri Lankan court. It advised the king on foreign trade policy. They also kept the king informed of developments abroad. The Muslim trader with his navigational skills and overseas contacts became the secret channel of communication between the court and the outside world".

The acting as envoys to the King was another important function of the Muslims in the Kandyan Court. One of the Muslim envoys had been sent to Nawab of Carnatic. In 1765, another one had been sent toward Pondicherry to solicit the assistance from French against impression of Dutch. Also, the King brought into play of his Muslim partisans to keep side by side of developments outside the kingdom. The Muslims were constructive in this respect due to their trade associations and knowledge of the languages (Dewaraja, 1994).

Because of these huge contributions of Muslims, by the Kandyan Kingdom, the Muslims were accepted favourably as we have seen. Robert Knox (1681) points out that the charitable Buddhists gifted the land to the Muslims for residing in it (Dewaraja, 1994). The Muslims adopted the external expression, the dress and the etiquette of the SinhalaBuddhists. James Cordiner (1807) writes that even it could not be found any differences in the appearances of the Buddhists and the Muslims in his research. There are yet two villages in Galagedara possessed main by the Muslims, encircled by the Sinhala villages. There were mosques in these two villages which were built on gifted lands by the Sinhala kings (Dewaraja, 1994). Also Meera Makkam and Katupalliya mosques in Kandy town were built on the land donated by the king and the architecture of Katupalliya is Kandyan too (Dewaraja, 1994). Kurunegala Ridi Vihare provided its part of land for a mosque and allocated a piece of land for the maintenance of a Muslim devotee (Dewaraja, 1994). A number of Muslim students were educated in the Buddhist temples in Rambukkana in 1930. Most of them studied Sinhala and home-grown medicine. They had been given the facilities for their prayers and attending the Qura'nic classes, while boarded in the temple. At the same time the Muslims dedicated them as volunteer to the 'Vihara' (Buddhist temple) and they took interest to participate in the 'Esala Perahera' in this village in Rambukkana, The drummers voluntarily quit the music when they passed the mosque (Nuhman, 2002).

There is plentiful evidence to prove that numerous Sri Lankan Muslims have a considerable mixture of the Sinhalese blood. James Cordiner (1807) points out that,

"the Sinhalese who profess the religion of Mohamed appear to be a mixed race, the principal of whose progenitors had emigrated from the peninsula of India. They are a much more active and industrious body of people than the Christians or the followers of Buddha".

The Akurana Muslims trace their descent to three Arabian private armies who got married the Kandyan Sinhalese women during the King Rajasinha's II reign (1635-1687) (Lawrie,1904) while the Gopala (Betge Nilame) clan, a very famous Muslim clan domiciled over Getaberiya in Kegalle area likewise claim descent from Arab physicians who landed in the country from 'Sind' during the reign of King Parakramabahu II (1236-1270) of 'Dambadeniya' and espoused Kandyan ladies (Dewaraja,1994). James Emerson Tennent (1859) specifies that "in the mountains of 'Ooda-kinda' in Western 'Oovah' is a small society known as the Paduguruwas who profess Islam, but conform to Kandyan customs", while H.W. Codrington (1996) describes Guruva as "a man of a blended race of the Sinhalese and Moor descent and of the Muhammadan religion in Uva". The Guruwo are also said to have been found in 'Dibburuwela' in the 'Udasiya Pattu' of Matale South.

This intermarriage among the Muslims and the Sinhalese was in evidence as well in the southern part of Sri Lanka and it is known to have proceeded until quite recent times. E.B. Denham (1912) writes,

"Amongst the Moors over Colombo and Galle at the present day there must be a fairly considerable infusion of Sinhalese blood; the number of Sinhalese women married to or living with Moors is fairly large".

In fact, the Muslims of the Buddhist region have had a tendency to bear some sort of resemblance to the Buddhist people amongst whom they live, which might indicate some admixture of Buddhist blood since at least Kandyan times. James Cordiner (1807), he went through a five years length of time in Sri Lanka (1799-1804), could barely differentiate a Muslim from a Buddhist. He refers to Sri Lankan Muslims as "the Cingalese who profess the religion of Mahomet". John Davy (1821), writes about the Muslims "In dress, appearance and manners, they differ but little from the Buddhists". Such interconnections have benefited the people in two ways; for one thing it has cleared the route 
of better understanding between the two communities, for there is no connection stronger than the blood relationship. Another thing, it is important that this racial intermixture strengths the community. The Muslims of Sri Lanka are often depicted as intelligent and venturesome individuals and this we can be practically certain is, to a large extent, attributable to their blended ancestry.

It is an unbelievable fact that the old Muslims are known to have purchased infants from their parents of other communities, who are excessively poor to keep up them, so that they could be cared as Muslims. In the latter part of the 19th century, G.A. Dharmaratna (1891) observed that "the Moors add to their number poor Buddhists' boys and girls who are duly received into their community". So that it is important to understand that the Buddhists contributed a considerable infusion of their blood to the Sri Lankan Muslims as well.

\subsection{During the Post-Independent Period (after 1915)}

The peaceful relationship continued until early in the twentieth century, when the Buddhist-Muslim riots of 1915 occurred. In this year, the British rulers and their affiliates at the time eventually exploited the undividable association between the communities to place a long haul in their relationship through the political strategy of divide and rule (Dewaraja, 1994). To a certain extent, the British colonial administration and their associations of the time succeeded in separating the relationship of two communities as a tactic of avoiding communities from arising as a challenge against their colonial rule. It was a grand plan to exploit and dominate the resources in the colony (Yehiya, 2013). Despite this outer set-up creating division, the relationship was versatile. Except during the 1915 incident, the cordial relationship between the Buddhists and the Muslims has continued in Sri Lanka, at least at the popular level until the end of the civil war (Haris, 2010) in 2009 between the government and the Liberation Tigers Tamil Elam (LTTE). There were no more records of any rupture between these two communities then this in the history.

The Muslims of Sri Lanka have given crucial support to the process of gaining independence from the British colony in 1948 and helped end nearly four and half centuries of European colonial rule in the island. Particularly, in the 1940s, the Muslim leaders such as Dr. M.C.M. Kaleel, Dr. T.B. Jaya, Dr. Badiuddin Mahmud and Sir Razick Fareed played a leading role at the doorstep of independence to Sri Lanka and provided their enthusiastic support for the demand of the dominion status and independence (Ameen, 2000). The Muslims never discouraged the political progress of Sri Lanka. In the aftermath of the World War II, protests for political restructuring and independence began to gather impetus. However, the British legislature demanded that three quarters of the populace ought to be backing the interest of the demand for independence to ensure the minority rights were protected. With the entire Sinhalese people comprising less than three quarters of the population this was an unattainable demand to fulfil unless minorities supported. The Tamil Congress leader G.G. Ponnambalm demanded equal representation, better known as fifty-fifty. Nonetheless, the Muslims stood wholly behind the Sinhalese majority and helped to meet the British demand for the support of two-thirds of the population (Farook, 2014). Henceforth, this shared characteristic of qualities fortified both groups to collectively become allies against the British colonialism that was bullying the country period by period.

In 1939, the way of address of Dr. Badiuddim Mahmud who was the secretary of the All Ceylon Muslim Political Conference at Colombo Zahira College ground, is a case in point for confirming the good relationship between the Buddhists and the Muslims. He said,

"let me assure my Sinhalese countrymen that I am one among them in demanding complete freedom for our country. They can count on me as one of the most ardent admirers of their legitimate national and cultural aspirations. In me and my community, let them know that they find the most trusted friends and kind neighbours in this island. They would never find wanting in me or in my community that unflinching loyalty and patriotism that this little island would demand one day from its sons and daughter to carve out a niche of fame for itself as a self-respecting unit in a world federation" (Farook, 2014).

It should also be pointed out that during the 1950's, when the official language issue was at its peak, the Muslim pioneers like Badiuddin Mahmud and Razik Fareed didn't consider it odd to be among the most eager advocates of the 'Sinhala Only' policy which sought to make Sinhala the only official language of Sri Lanka, replacing English period. Regardless, the Muslim constituencies they represented were for the main part a Tamil-speaking people. In fact, the powerful Muslim Minister in the 1970's under the left-leaning United Front Government Dr. Badiuddin Mahmud is known to have propagated among his southern coreligionists as far back as the 1950s the need to learn Sinhala language and should adopt it as their mother language (The Islamic Socialist Front, 1969). There are even those who believe that Dr. Mahmud was the first Sri Lankan who wanted the Sinhala as the main official dialect in an independent Sri Lanka. As far back as 1938, addressing the Galle Muslims, he is known to have proclaimed that 
"Muslims did not get any benefit by accepting Tamil language. Today or tomorrow, we will definitely get independence and Sinhala should be the official language" (De Silva, 1984).

A number of Muslim students in Buddhist predominant areas receive their schooling today in the Sinhala as the medium of instructions. Nuhman (2007) observes that,

"There is a growing tendency among the school going generation who study in the Sinhala medium, to use Sinhala as their first language and speak in Sinhala even with their Muslim friends and parents. They do not read and write Tamil, that shows a shift in their mother tongue".

As a result, during the time of independence, Sri Lanka was one of best nations in the world to live there was political stability, sufficient foreign reserve, economic growth, well developed health care and education system and communal harmony and peace.

\section{Conclusion}

A few scholars expressing their opinion based on their studies that the Buddhist-Muslim riots in 1915 this, was the result of the policy of divide and rule and communal politics which the British initiated from 1976 onward (Dewaraja, 1994). Kumari Jayawardana (1986) traces a different augment that the evolution of Sinhala - Buddhists consciousness that had originally arisen as a base for the struggle for national independence. This consciousness was at one stage directed against the colonial power but unfortunately it also contained elements of Sinhala chauvinism that adversely affected other ethnic groups. Therefore, this is an accidentally held event in the history. Another opinion that these riots were not directed against all the Muslims, but more specifically against a section of the Muslim community who lived in coastal areas of Sri Lanka (Haris, 2010).

Through these statements, it could be assumed that there were some outside influences interfered on the relationship between these two societies. Anyhow, despite rising prejudice around 1930, there was communal harmony at a popular level (Farook, 2014). According to Haris (2010), the majority of the Buddhists are having favourable opinions of Islam and Muslims and they are interested in interacting with the Muslim from the early period to date. Despite the Tamils and the Muslims speaking the same language -Tamil and sharing number of cultural practices with the Muslims, the Muslims never got attempt to make better relationship with Tamils. But the Muslims have been maintaining a cordial relationship with the Buddhists society since early periods onward, even though the evils somewhat prevailed in the relationship with the Sinhalese (Victor, 1997). Supporting the 'Sinhala only' Bill of S.W.R.D. Bandaranayka and avoiding the G.G. Ponnamplam's fifty-fifty demand are better examples for this. Therefore, finally, it came to a main decision that, although many attempts were made by the Buddhists to marginalize themselves from the Muslims, the Muslims have still been chasing behind them to keep up better relationship with them.

\section{References}

Ameen, M.I.M. (2000). Ilankai Muslimkalin Waralarum Kalasaramum 1870-1915. Hemmathagama: Al-Hasanath publication.

Codrington, H.W. (1996). Glossary of Native, Foreign, and Anglicised Words: commonly used in Ceylon in official correspondence and other. New Delhi: Asian Educational Services.

Cordiner, J. (1807). A Description of Ceylon, Containing an Account of the Country, Inhabitants, and natural Production: With Narratives of a tour round the Island in 1800, the Campaign in Candy in 1803, and a Journey to Ramisseram in 1804. London: Longman, Hurst, Rees, Orme, and Brown.

Dharmaratna, G.A. (1891). The Kara-Goi Contest with an Appeal to the House of Commons. Galle, Sri Lanka: Independent Press.

Davy, J. (1821). Account of the Interior of Ceylon and of its inhabitants. London: Longman, Hurst, Rees, Orme, and Brown.

Dewaraja, L. (1994). The Muslims of Sri Lanka One Thousand Years of Ethnic Harmony 900-1915. Colombo: The Lanka Islamic Foundation.

De Silva, K.M. (1984). The Muslim Minority in a Democratic Polity: The case of Sri Lanka. In M.A.M. Shukri, Muslims of Sri Lanka: Avenues to Antiquity (pp. 443-451). Beruwela: Jamiah Naleemiah Institution.

De Silva, K.M. (1984). Muslim Leaders and the Nationalist Movement, In M.A.M. Shukri, Muslims of Sri Lanka Avenues to Antiquity (pp. 453-472). Beruwela: Jamiah Naleemiah Institution.

Department of Census and Statistics-Sri Lanka. (2012). Statistical Abstract of the Democratic Socialist Republic of Sri Lanka. Retrieved from http://www.researchgate.net/researcher/2036515296_Sri_Lanka_Dept_of_Census_and_Statistics

Denham, E.B. (1912). Ceylon at the Census of 1911.being the review of the results of the census of 1911. Colombo: H.C. Cottle, Government Printer.

Emerson Tennent, J. (1859). Ceylon; an Account of the Island Physical, Historical and Topographicla, with Notices of its Natural History, 
Antiquities, and Productions. London: Longman, Green, and Roberts.

Farook, L. (2014). Muslims of Sri Lanka Under Siege. Colombo: Latheef Farook.

Haniffa, R. (2010). The Sri Lankan Muslim Minority: A Bridge to Harmony. Retrieved from http://dbsjeyaraj.com/dbsj/archives/1706.

Hussein, A. (2010). The Unbreakable Bond Why Sinhalese-Muslim relations have stood the test of time. Retrieved from http://www. sailanmuslim.com/news/wpcontent/themes/newspress/images/Sinhalese-Muslim\%20Relations.pdf

Jayawardena, K. (1986). Ethnic and Class conflicts in Sri Lanka. Dehiwela, Sri Lanka: Centre for Social Analysis.

Lawrie, A.C. (1904). A Gazzetteer of the Central Province of Ceylon, In Ceylon. Commission, Louisiana Purchase Exposition, St. Louis, Official Handbook of the Ceylon Court, Colombo: George .J .A. Skeen.

Lebbe, M. H. H. (2010). Buddhists' perceptions of Islam and Muslims in Sri Lanka: an empirical study in the context of Da'wah (Unpublished PhD Thesis). International Islamic University Malaysia, Gombak, Malaysia.

Nuhman, M.A. (2002). Understanding Sri Lankan Muslim Identity. Colombo: international Centre for Ethnic Studies.

Nuhman, M.A. (2007). Sri Lankan Muslims, Ethnic Identity within Cultural Diversity. Colombo: International Centre for Ethnic Studies.

Peiris, K. (2013). The Muslims and Sri Lanka. Retrieved from http://www.sailanmuslim.com/news/the-muslims-and-sri-lanka-bykamalika-pieris/

Pieris, P.E. (1913). Ceylon: The Portuguese Era: Being a History of the Island for the Period 1505-1658. Colombo: Colombo Apothecaries.

Razick, A.S. (2007). Moneragalai Mawatta Muslimkalin Waralaru (Unpublished bachelor degree dissertation). South Eastern University of Sri Lanka, Oluvil, Sri Lanka.

Razick, A.S., Long, A.S. \& Salleh, K. (2015). Relationship between the Sinhalese and the Muslims in Sri Lanka: A Bibliographical Survey. Journal of Humanities and Social Science, 20(5). pp. 65-70.

The Travels of Marco Polo, (1958). trans. by R. E. Letham, London: Penguin Books.

The Travels of Ibn Battuta, (1970). trans. by H.A.R. Gibb, New Delhi: Goodword Books.

The Islamic Socialist Front, (1969). A brief life sketch Dr. Al-Haj Badiudin Mahmud, Colombo: The Islamic Socialist Front.

Victor, I. (1997). Muslim Thesamum Ethirkazhamum. Akkaraipattu, Sri Lanka: Munrawathu Manithan.

Yehiya, R. (2013). Asymmetric relationship of Buddhist-Muslim bond in Sri Lanka. Retrieved from http://groundviews.org/2013/06/01/theasymmetric-relationship-of-buddhist-muslim-bond-in-sri-lankal

Yusoff, M.A., Hussin, N., \& Sarjoon, A. (2014). Positioning Muslims in Ethnic Relations, Ethnic Conflict and Peace Process in Sri Lanka. Asian Social Science, 10, 199-211. http://dx.doi.org/10.5539/ass.v10n10p199 